\title{
Mechanism of anticancer action of novel berenil complex of platinum(II) combined with anti-MUC1 in MCF-7 breast cancer cells
}

\author{
AGNIESZKA GORNOWICZ ${ }^{1}$, ANNA BIELAWSKA ${ }^{1}$, WOJCIECH SZYMANOWSKI ${ }^{1}$, \\ HALINA GABRYEL-POROWSKA ${ }^{2}$, ROBERT CZARNOMYSY ${ }^{3}$ and KRZYSZTOF BIELAWSKI ${ }^{3}$ \\ Departments of ${ }^{1}$ Biotechnology, ${ }^{2}$ Medical Chemistry and ${ }^{3}$ Synthesis and Technology of Drugs, \\ Medical University of Bialystok, 15-222 Bialystok, Poland
}

Received August 3, 2017; Accepted November 20, 2017

DOI: $10.3892 / \mathrm{ol} .2017 .7623$

\begin{abstract}
Mucin 1 (MUC1) is a high molecular weight transmembrane glycoprotein, that is overexpressed in $>90 \%$ of breast cancers. It serves a crucial role in anti-apoptosis and tumor progression. MUC1 interacts with proteins in the extracellular matrix, at the cell membrane, in the cytoplasm and in the nucleus. The aim of the present study was to investigate the mechanism of anticancer action induced by novel berenil complex of platinum(II) (Pt12) together with a monoclonal antibody against MUC1 in breast cancer MCF-7 cells. The effect of combined treatment on the concentration of selected markers of apoptosis including proapoptotic B-cell lymphoma 2 associated $\mathrm{X}$ protein (Bax), caspase-8, cytochrome $c$ and caspase-9, as well as selected proteins involved in intracellular signal transduction pathways including p53, phosphoinositide 3-kinase and phosphorylated protein kinase B (p-Akt) were analyzed. The results of the present study demonstrated that combined treatment may be a promising strategy in anticancer treatment and represents an alternative to monotherapy. All compounds used alone (Pt12, cisplatin and the anti-MUC1 antibody) increased the concentration of proapoptotic Bax, cytochrome $c$ and caspase-9 in comparison with control, thus suggesting that they activated the mitochondrial apoptotic pathway. Pt12 alone significantly increased the concentration of caspase-8, which is responsible for the initiation of the extrinsic apoptotic pathway. However, the strongest effect was observed following Pt12 $(20 \mu \mathrm{M})$ treatment combined with the anti-MUC1 antibody (10 $\mu \mathrm{g} / \mathrm{ml})$. These two compounds together strongly induced apoptosis in MCF-7 breast cancer
\end{abstract}

Correspondence to: Dr Agnieszka Gornowicz, Department of Biotechnology, Medical University of Bialystok, Kilinskiego 1, 15-222 Bialystok, Poland

E-mail: agnieszka.gornowicz@umb.edu.pl

Key words: anti-mucin 1, platinum complexes, apoptotic markers, breast cancer, phosphoinositide 3-kinase/protein kinase B signaling pathway cells via the external and internal apoptotic pathways. It was also demonstrated that combined treatment based on Pt12 and the anti-MUC1 antibody significantly reduced p-Akt concentration.

\section{Introduction}

MUC1, a member of mucin family is overexpressed in many tumors, but especially in breast cancer. In normal conditions, MUC1 expression is limited to the apical surface of most ductal epithelium. In metastatic disease, MUC1 becomes localized throughout the cell (1). In many tumor types its expression correlates with poor response to therapy and poor survival. MUC1 is involved in metastatic progression through both its extracellular and intracellular domains. It acts as a cofactor for gene transcription and interacts with proteins in the extracellular matrix, at the cell membrane, in the cytoplasm, and in the nucleus (2). MUC1 interacts with four ErbB receptors, but the best characterized is MUC1-EGFR interaction (3-5). MUC1 associates with adhesion molecules such as intercellular cell adhesion molecule-1 (ICAM-1) (6,7), members of Src-family kinases (c-Src, Lyn, Lck) (8-12), components of Wnt-signaling pathway (13) and MAP kinase pathway, estrogen receptor $\alpha$ (14), p53 (3), and heat shock protein 90 (HSP90) (15). MUC1 also activates the PI3K-Akt pathway and increases the expression of the antiapoptotic protein by a PI3K-independent mechanism in vitro (16).

The phosphoinositide 3 kinase (PI3K)/Akt/mammalian target of rapamycin (mTOR) (PAM) pathway is the most frequently altered pathway in human cancers. Activation of the PAM pathway has been estimated to be in as frequent as $70 \%$ of breast cancers overall (17). The PI3Ks are a family of lipid kinases divided into three classes according to the sequence homology, substrate preference and tissue distribution (18). Binding of a growth factor or ligand to its cognate members of the human epidermal growth factor receptor (HER) family, the insulin and insulin-like growth factor 1 (IGF-1) receptor and others initiates the activation of PI3K, which phosphorylates phosphatidylinositol 4,5-bisphosphate (PIP2) to phosphatidylinositol 3-5-triphosphate (PIP3) and in turn leads to phosphorylation of Akt (19-21). Akt stimulates cell 
cycle progression and proliferation by modulating cell cycle inhibitors, such as p21, p27kip1 and GSK3, and cell cycle stimulators, such as c-myc and cyclin D1 (22). Akt also takes part in programmed cell death through inhibition of both proapoptotic genes (FasL and Bim) and proteins (BAD and Bax), stimulation of anti- apoptotic proteins $(\mathrm{NF}-\alpha \mathrm{K})$ and degradation of the tumor suppressor protein p53 $(18,23)$. Phosphorylation of Akt stimulates protein synthesis and cell growth by activating mTOR, which is a serine/threonine protein kinase. It is present in two protein complexes, mTOR complex 1 (mTORC1) and mTOR complex 2 (mTORC2), which are structurally similar but functionally different (24). mTORC1 leads to cell anabolic growth by promoting mRNA translocation and protein synthesis and also has roles in glucose metabolism and lipid synthesis, while mTORC2 organizes the cellular actin cytoskeleton and regulates AKT phosphorylation (24-26).

The classical Pt-based anticancer drugs such as cisplatin are useful in the treatment of many tumors. Cisplatin binds to the major groove of DNA and its cytotoxicity is associated with inhibition of DNA synthesis and replication by formation of bifunctional interstrand and intrastrand crosslinks $(27,28)$. In the recent years, we obtained in our laboratory a series of novel dinuclear platinum(II) complexes containing berenil and amine ligands. The compounds display higher antitumor activity than cisplatin. Berenil [1,3-bis(4'-amidinophenyl) triazene] recognizes AT rich DNA sequences and it is a strong inhibitor of DNA topoisomerase II $(29,30)$. Moreover, our complexes bind to the DNA minor groove and form different types of complex-DNA adducts than cisplatin $(31,32)$. The dinuclear berenil platinum complexes with amine ligands are cationic in nature and show excellent solubility in water. The analysis of the structure-activity relationship of the dinuclear complexes showed that berenil provided H-bonding and an electrostatic pre-association with duplex DNA in the minor groove. The pre-covalent binding association can be used to control the site of platination through an increased local concentration at particular sites on DNA. The berenil platinum complexes differentiate this from other alkylating agents, which primarily relate to the major groove of DNA. Structurally novel platinum complexes that bind to DNA differently than cisplatin may have distinct cytotoxicity and side effect profiles $(33,34)$.

MUC1 is a type I transmembrane glycoprotein that is aberrantly overexpressed in various cancer cells especially in breast cancer cells There are known research works about combined therapy with monoclonal antibody C595 and docetaxel in several ovarian cell cancers, but there are no data about combined therapy based on platinum compounds with anti-MUC1 antibody in breast cancer cell lines. A novel dinuclear platinum(II) complex (Pt12) used with anti-MUC1 was compared to its parent drug and cisplatin with anti-MUC1 in respect to cytotoxicity, DNA, and collagen biosynthesis in MDA-MB-231 and MCF-7 human breast cancer cells. It was found that Pt12 with anti-MUC1 was more active inhibitor of DNA and collagen synthesis as well more cytotoxic agent than Pt12 alone and cisplatin with anti-MUC1. That was the preliminary study which gave the basis for further analysis of molecular mechanism of action.

The aim of the study was to check the mechanism of action induced by novel berenil complex of platinum(II)-Pt12 together with monoclonal antibody against MUC1 in estrogen receptor positive breast cancer MCF-7 cells. We analyzed the effect of the combined treatment on the concentration of selected markers of apoptosis such as proapoptotic Bax, markers associated with external (caspase-8) and internal apoptotic pathways (cytochrome $c$, caspase-9). The key element of the study was to check the influence of combined treatment on the concentration of selected proteins involved in intracellular signal transduction pathways. We checked the concentration of p53, PI3K and p-Akt.

\section{Materials and methods}

Materials. Cisplatin, monoclonal antibody anti-MUC1 GP1.4 were purchased from Sigma-Aldrich; Merck KGaA (Darmstadt, Germany). Stock cultures of human MCF-7 breast cancer cells were purchased from the American Type Culture Collection (Manassas, VA, USA). Dulbecco's modified Eagle's medium (DMEM) and fetal bovine serum (FBS) used in a cell culture were products of Gibco (Thermo Fisher Scientific, Inc., Waltham, MA, USA). Glutamine, penicillin and streptomycin were obtained from Quality Biologicals Inc. (Gaithersburg, MD, USA). ELISA's kits were purchased from USCN Life Science Inc. (Wuhan, China), BioVendor (Brno, Czech Republic) and MyBioSource (San Diego, CA, USA). The chemical synthesis and structure of Pt12 was presented in publication (35).

Cell culture MCF-7. Estrogen receptor positive breast cancer MCF-7 cells were maintained in DMEM supplemented with $10 \%$ FBS, $2 \mathrm{mM}$ glutamine, $50 \mathrm{U} / \mathrm{ml}$ penicillin, $50 \mathrm{mg} / \mathrm{ml}$ streptomycin at $37^{\circ} \mathrm{C}$ in a humidified atmosphere containing $5 \% \mathrm{CO}_{2}$.

We have performed the preliminary studies based on MTT assay for monotherapy and combined treatment. We determined $\mathrm{IC}_{50}$ values for anti-MUC1 antibody and it was $20 \mu \mathrm{g} / \mathrm{ml}$. We reduced the dose of monoclonal antibody to $1 / 2$ $\mathrm{IC}_{50}-10 \mu \mathrm{g} / \mathrm{ml}$. The same experiment was done for Pt12. $\mathrm{IC}_{50}$ value for Pt12 was $17 \pm 2 \mu \mathrm{M}$. We have chosen two concentrations: $1 / 2 \mathrm{IC}_{50} \pm 2 \mu \mathrm{M}(10 \mu \mathrm{M})$ and $\mathrm{IC}_{50} \pm 2 \mu \mathrm{M}(20 \mu \mathrm{M})$ cisplatin was used as a reference in the same doses as our tested novel compound (Pt12). These results were obtained after $24 \mathrm{~h}$ of incubation with tested compounds and were satisfactory. Furher studies were done after $24 \mathrm{~h}$ of incubation with tested compounds. Cells were incubated with anti-MUC1 $(10 \mu \mathrm{g} / \mathrm{ml})$, Pt12 $(10 \mu \mathrm{M}), \operatorname{Pt} 12+$ anti-MUC1 $(10 \mu \mathrm{M}+10 \mu \mathrm{g} / \mathrm{ml})$, cisplatin $(10 \mu \mathrm{M})$, cisplatin + anti-MUC1 $(10 \mu \mathrm{M}+10 \mu \mathrm{g} / \mathrm{ml})$ for $24 \mathrm{~h}$ and used to prepare cells lysates. Briefly, trypsinized cells were washed three times with cold PBS and centrifuged at $1,000 \mathrm{xg}$ for $5 \mathrm{~min}$ at $4^{\circ} \mathrm{C}$. The cells $\left(1 \times 10^{6}\right)$ were suspended in lysis buffer for whole cell lysates. After centrifugation the supernatants were frozen immediately at $-70^{\circ}$. The concentration of propapoptotic markers and proteins involved in intracellular signal transduction pathways was measured. Cells without addition of compounds were treated as controls.

Determination of proapoptotic Bax protein. The high sensitivity assay kit (SEB343Hu; USCN Life Science Inc.) was used to determine the concentration of proapoptotic Bax protein in cell lysates. The microtiter plate provided has been pre-coated 
with a monoclonal antibody specific to Bax. Standards and samples were added to the appropriate microtiter plate wells and incubated for $2 \mathrm{~h}$ at $37^{\circ} \mathrm{C}$. After the first incubation step, a biotin-conjugated polyclonal antibody specific for Bax was pipetted and incubated for $1 \mathrm{~h}$ at $37^{\circ} \mathrm{C}$. After washing away any unbound substances, avidin conjugated to horseradish peroxidase (HRP) was added to each microplate well and incubated. After another aspiration and washing step, a TMB substrate solution was added to each well. The enzyme-substrate reaction was terminated by the addition of a sulfuric acid solution and the color change was measured at a wavelength of $450 \mathrm{~nm}$. The assay was performed in duplicate and the concentration of Bax in the samples was then determined by comparing the OD of the samples to the standard curve. The range of the standard curve for Bax was: $0.78-50 \mathrm{ng} / \mathrm{ml}$. The minimum detectable dose (MDD) of human Bax was generally less than $0.32 \mathrm{ng} / \mathrm{ml}$.

Determination of caspase- 8 and caspase-9. Caspase- 8 and caspase- 9 concentrations in cell lysates were determined by using an enzyme-linked immunosorbent assay kit (nos. RBMS2024R and RBMS2025R; BioVendor). Monoclonal antibodies specific to caspase- 8 or caspase- 9 were pre-coated onto a microplate. Standards and samples (100 $\mu \mathrm{l}$ each) were pipetted into the wells in duplicate and antigen was bound by the immobilized antibody. The working solution of antibody was also added to all wells. Then the microplate was incubated for $2 \mathrm{~h}$ at room temperature (RT). After washing away any unbound substances, an enzyme-linked polyclonal antibody specific for caspase-8 or caspase-9 (100 $\mu \mathrm{l})$ was added to each well for $1 \mathrm{~h}$ at RT. Following a wash to remove any unbound antibody enzyme-reagent, a substrate solution $(100 \mu \mathrm{l})$ was added to the wells for $15 \mathrm{~min}$; the color developed in proportion to the amount of antigen bound in the initial step. Color development was stopped by phosphoric acid, and the intensity of the color was measured at a wavelength of $450 \mathrm{~nm}$. The MDD of caspase- 8 was $0.1 \mathrm{ng} / \mathrm{ml}$ and caspase- 9 was: $0.4 \mathrm{ng} / \mathrm{ml}$. The concentrations of the samples were calculated from the standard curve and ranged from 0.16 to $10 \mathrm{ng} / \mathrm{ml}$ for caspase- 8 and 1.6 to $100 \mathrm{ng} / \mathrm{ml}$ for caspase-9. The results were presented in nanogram per milliliter $(\mathrm{ng} / \mathrm{ml})$. There was no cross-reactivity with other caspases.

Determination of cytochrome c and p53 protein. Cytochrome $c$ and p53 concentrations in cell lysates were determined by using an enzyme-linked immunosorbent assay kit (nos. RBMS263R and RBMS256R; BioVendor). Anti-human cytochrome $c$ or anti-human p53 antibody was pre-coated onto a microplate. Standards and samples were added into appropriate wells and biotin conjugate was also pipetted to all wells. The plate was incubated at RT for $2 \mathrm{~h}$. After wash step, streptavidin-HRP was added into all wells and plate was incubated for next $1 \mathrm{~h}$ in RT. After incubation, unbound streptavidin-HRP was removed during a wash step and substrate solution was added to the wells. A colored product was formed in proportion to the amount of antigen present in the sample or standard. The reaction was terminated by addition of acid and absorbance was measured at $450 \mathrm{~nm}$. The concentrations of the samples were calculated from the standard curve. The samples for cytochrome $c$ assessment were diluted and then multiplied by the dilution factor. The standard curve ranged from 0.08 to $5 \mathrm{ng} / \mathrm{ml}$ for cytochrome $c$ and 0.78 to $50 \mathrm{U} / \mathrm{ml}$ for human 533 .

Determination of human phosphotylinosital 3 kinase (PI3K). Human PI3K concentration in cell lysates was determined by using an enzyme-linked immunosorbent assay kit (MBS9303190; MyBioSource). PI3K-specific antibody was pre-coated onto a microplate. Standards and samples were pipetted into the wells and any PI3K present was bound by the immobilized antibody. After removing any unbound substances, a biotin-conjugated PI3K-specific antibody was added to the wells. After washing, avidin conjugated HRP was added to the wells. Following a wash to remove any unbound avidin-enzyme reagent, a substrate solution was added to the wells and color developed in proportion to the amount of PI3K bound in the initial step. The color development was stopped and the intensity of the color was measured. The MDD of PI3K was typically less than $0.156 \mathrm{ng} / \mathrm{ml}$. The concentrations of the samples were calculated from the standard curve and ranged from 0.625 to $40 \mathrm{ng} / \mathrm{ml}$. The results were presented in nanogram per mililiter (ng/ml).

Determination of phospho-Akt. Phospho-Akt concentration in cell lysates was determined by using an enzyme-linked immunosorbent assay kit (MBS396298; MyBioSource). An antibody, specific to the non-phospho and phospho Akt1 protein was immobilized onto the surface of microtiter wells provided in the kit. Using this ELISA, cross-reactivity with unphosphorylated Akt1, Akt2, and Akt3 is minimal. The samples (cell lysate) to be assayed were pipetted into the wells and allowed to incubate for two h (or overnight for higher sensitivity), during which time any Akt1 present binds to the capture antibodies. Unbound material was washed away and a biotin conjugated anti-phospho Akt1 antibody was added to the wells and incubated for $2 \mathrm{~h}$ at RT. Excess biotin conjugate was removed by washing and a HRP-conjugated streptavidin was added for $30 \mathrm{~min}$. Excess HRP conjugate was removed by washing. The HRP catalyzed the conversion of the chromogenic substrate tetra-methylbenzidine (TMB) (30 min incubation) from a colorless solution to a blue solution (or yellow after the addition of stop reagent), the intensity of which was proportional to the amount of phospho Akt1 protein in the sample. The coloured reaction product was quantified using a spectrophotometer. The concentrations were calculated from the standard curve and ranged from 0.25 to $20 \mathrm{ng} / \mathrm{ml}$.

Caspase- 8 enzymatic activity assay. Caspase- 8 activity was measured using FAM-FLICA Caspase-8 kit (no. 910; ImmunoChemistry Technologies, Bloomington, MN, USA) according to the manufacturer's instructions. The human MCF-7 breast cancer cells were treated with the tested compounds for $24 \mathrm{~h}$, and then harvested and washed with cold buffer PBS. A total of $5 \mu \mathrm{l}$ of diluted FLICA reagent and $2 \mu \mathrm{l}$ of Hoechst 33342 were added to $93 \mu \mathrm{l}$ of cell suspension and mixed by pipetting. The cells were incubated for $60 \mathrm{~min}$ at $37^{\circ} \mathrm{C}$. After incubation, the cells were washed twice in $400 \mu 1$ apoptosis wash buffer and centrifuged at $300 \mathrm{x} \mathrm{g}$. After the last wash, the resuspended cells in $100 \mu \mathrm{l}$ apoptosis wash buffer were supplemented with 


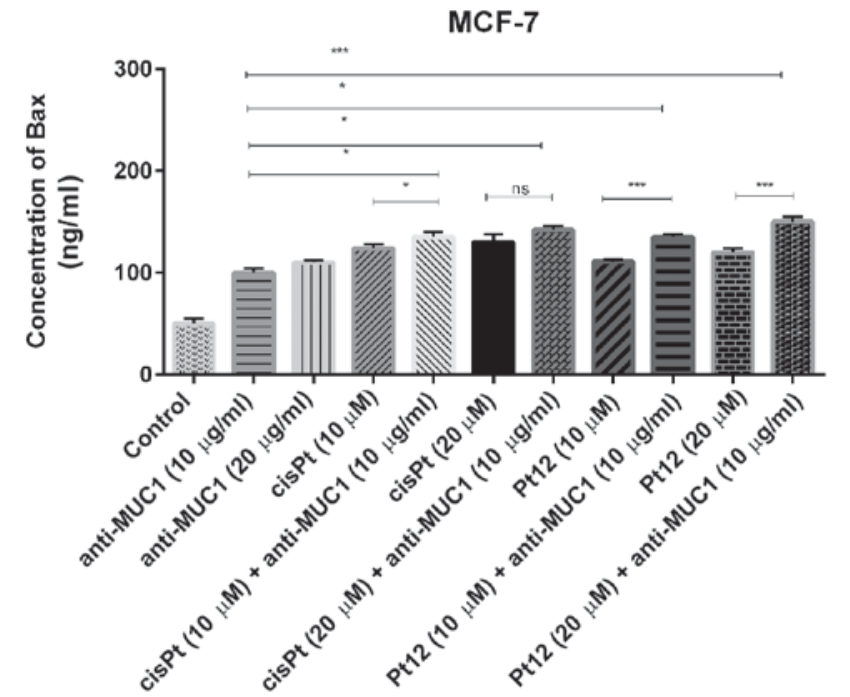

Figure 1. Concentration of pro-apoptotic Bax protein in breast cancer MCF-7 cells following $24 \mathrm{~h}$ incubation with anti-MUC1 $(10$ and $20 \mu \mathrm{g} / \mathrm{ml}), \operatorname{Pt} 12(10$ and $20 \mu \mathrm{M}), \mathrm{Pt} 12+\operatorname{anti}-\mathrm{MUC} 1(10 \mu \mathrm{M}+10 \mu \mathrm{g} / \mathrm{ml}$ and $20 \mu \mathrm{M}+10 \mu \mathrm{g} / \mathrm{ml})$, cisplatin $(10$ and $20 \mu \mathrm{M})$, cisplatin + anti-MUC1 $(10 \mu \mathrm{M}+10 \mu \mathrm{g} / \mathrm{ml}$ and $20 \mu \mathrm{M}+10 \mu \mathrm{g} / \mathrm{ml})$. The results are representative of data from 3 independent experiments. Data presented as the mean \pm standard deviation. ${ }^{*} \mathrm{P}<0.05$ and ${ }^{* * * *} \mathrm{P}<0.001$, as indicated. Bax, B-cell lymphoma 2-associated X protein; MUC1, mucin 1; Pt12, platinum(II) complex; ns, not significant.

$10 \mu \mathrm{g} / \mathrm{ml}$ PI. Analysis was performed using the BD FACSCanto II flow cytometer, and results were analyzed with FACSDiva software (both from BD Biosciences, San Jose, CA, USA).

Caspase-9 enzymatic activity assay. Caspase-9 activity was measured using FAM-FLICA Caspase-9 Kit (no. 913; ImmunoChemistry Technologies) according to the manufacturer's instructions. The MCF-7 human breast cancer cells were treated with the tested compounds for $24 \mathrm{~h}$, and then harvested and washed with cold buffer PBS. $5 \mu$ l of diluted FLICA reagent and $2 \mu \mathrm{l}$ of Hoechst 33342 were added to $93 \mu 1$ of cell suspension and mixed by pipetting. The cells were incubated for $60 \mathrm{~min}$ at $37^{\circ} \mathrm{C}$. After incubation, the cells were washed twice in $400 \mu \mathrm{l}$ apoptosis wash buffer and centrifuged at $300 \mathrm{x} \mathrm{g}$. After the last wash, the resuspended cells in $100 \mu \mathrm{l}$ apoptosis wash buffer were supplemented with $10 \mu \mathrm{g} / \mathrm{ml} \mathrm{PI}$. Analysis was performed using the BD FACSCanto II flow cytometer, and results were analyzed with FACSDiva software (both from BD Biosciences).

Statistical analysis. Experimental data were presented as means \pm standard deviation since each experiment was repeated three times. One way Anova (Dunnett's multiple comparisons test) was performed to demonstrate the difference between single and combined treatments. A statistically significant difference was defined at $\mathrm{P}<0.05$. Statistical analysis was performed using GraphPad Prism Version 6.0 (GraphPad Software, Inc., La Jolla, CA, USA).

\section{Results}

Impact of Pt12 combined with anti-MUCl antibody on the intrinsic apoptotic pathway. In our study, we performed

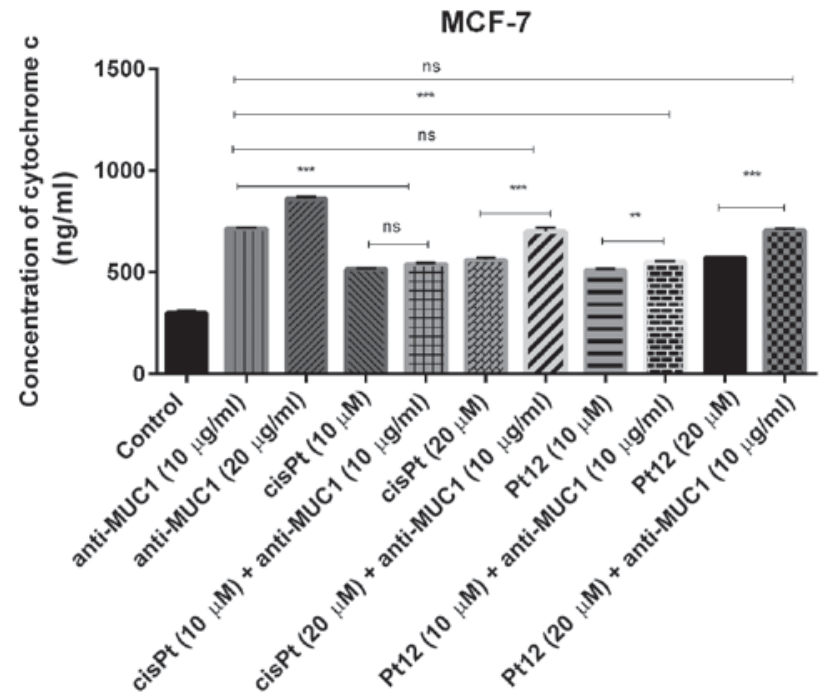

Figure 2. Concentration of cytochrome $\mathrm{c}$ in breast cancer MCF-7 cells following $24 \mathrm{~h}$ incubation with anti-MUC1 (10 and $20 \mu \mathrm{g} / \mathrm{ml}), \mathrm{Pt1} 2$ (10 and $20 \mu \mathrm{M}), \mathrm{Pt} 12+\operatorname{anti}-\mathrm{MUC} 1(10 \mu \mathrm{M}+10 \mu \mathrm{g} / \mathrm{ml}$ and $20 \mu \mathrm{M}+10 \mu \mathrm{g} / \mathrm{ml})$, cisplatin $(10$ and $20 \mu \mathrm{M})$, cisplatin + anti-MUC1 $(10 \mu \mathrm{M}+10 \mu \mathrm{g} / \mathrm{ml}$ and $20 \mu \mathrm{M}+10 \mu \mathrm{g} / \mathrm{ml}$ ). The results are representative of data from 3 independent experiments. Data presented as the mean \pm standard deviation. ${ }^{* *} \mathrm{P}<0.01$ and ${ }^{* * * *} \mathrm{P}<0.001$, as indicated. MUC1, mucin 1; Pt12, platinum(II) complex; ns, not significant.

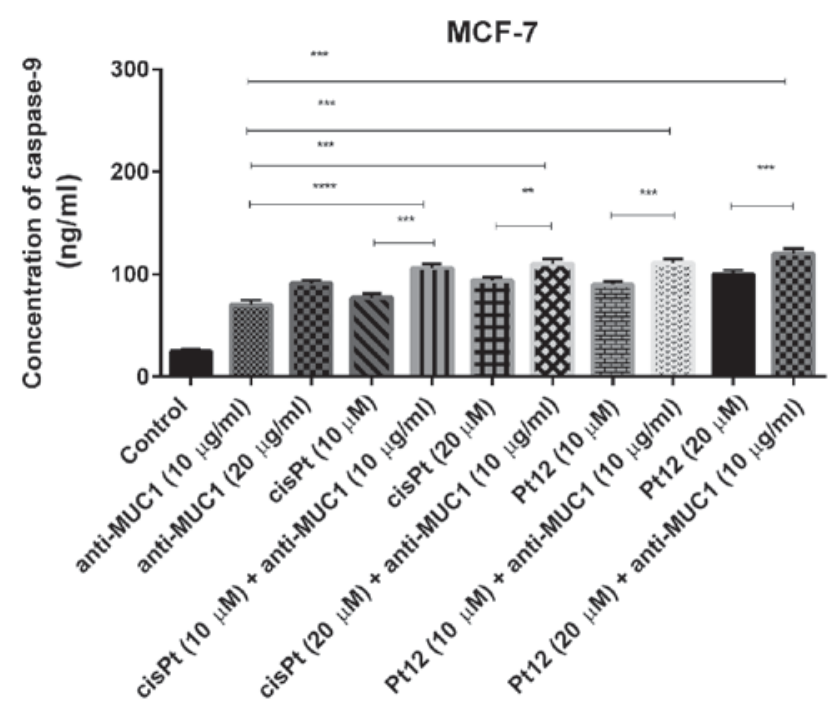

Figure 3. Concentration of caspase-9 in breast cancer MCF-7 cells following $24 \mathrm{~h}$ incubation with anti-MUC1 $(10$ and $20 \mu \mathrm{g} / \mathrm{ml}), \mathrm{Pt} 12(10$ and $20 \mu \mathrm{M})$, Pt12 + anti-MUC1 $(10 \mu \mathrm{M}+10 \mu \mathrm{g} / \mathrm{ml}$ and $20 \mu \mathrm{M}+10 \mu \mathrm{g} / \mathrm{ml})$, cisplatin $(10$ and $20 \mu \mathrm{M})$, cisplatin + anti-MUC1 $(10 \mu \mathrm{M}+10 \mu \mathrm{g} / \mathrm{ml}$ and $20 \mu \mathrm{M}+10 \mu \mathrm{g} / \mathrm{ml})$. The results are representative of data from 3 independent experiments. Data presented as the mean \pm standard deviation. ${ }^{* *} \mathrm{P}<0.01$ and ${ }^{* * *} \mathrm{P}<0.001$, as indicated. MUC1, mucin 1; Pt12, platinum(II) complex.

ELISA measurements to check the concentration of selected markers of apoptosis such as: Proapoptotic Bax, markers associated with external (caspase-8) and internal apoptotic pathways (cytochrome $c$, caspase-9).

The breast cancer MCF-7 cells were incubated for $24 \mathrm{~h}$ with the tested compounds. We used the compounds alone-anti-MUC1 antibody at two concentrations: 10 and $20 \mu \mathrm{g} / \mathrm{ml}$, cisplatin and Pt12 at two concentrations: 10 and $20 \mu \mathrm{M}$. We checked the combined effects of anti-MUC1 

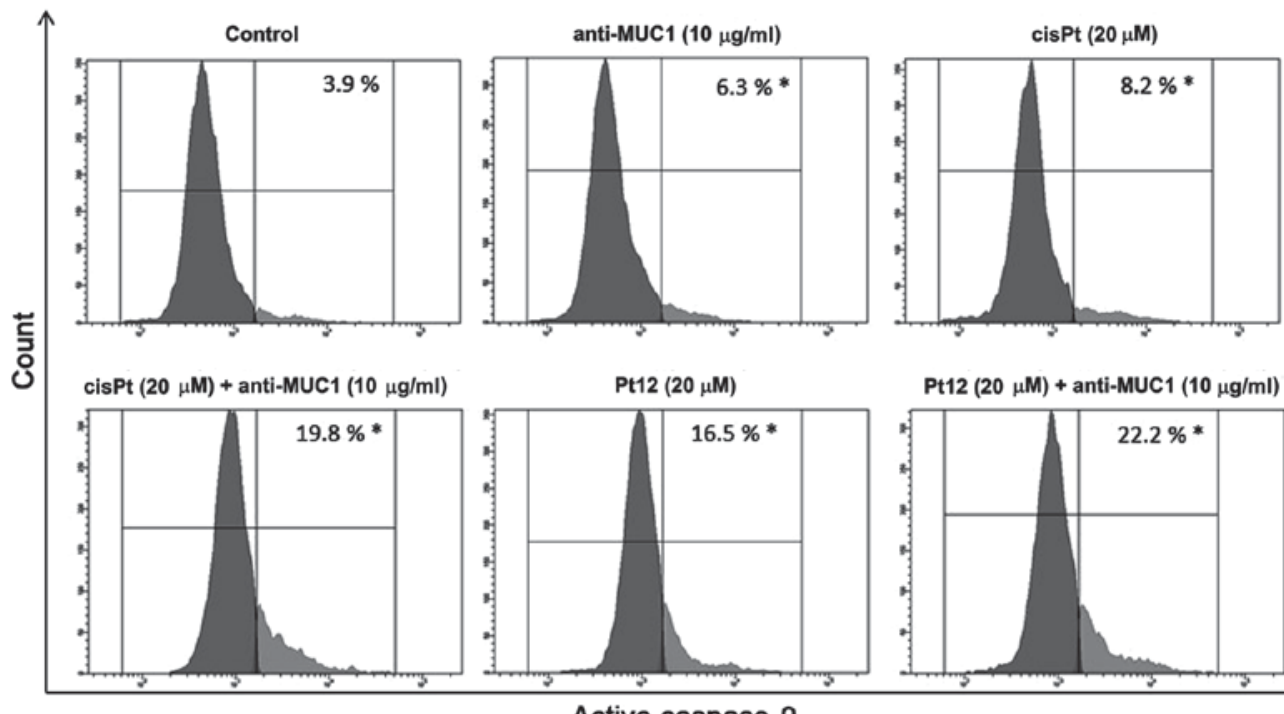

Pt12 $(20 \mu \mathrm{M})+$ anti-MUC1 $(10 \mu \mathrm{g} / \mathrm{ml})$

Active caspase-9

Figure 4. Activity of caspase-9 in breast cancer MCF-7 cells following $24 \mathrm{~h}$ incubation with anti-MUC1 (10 $\mu \mathrm{g} / \mathrm{ml}), \mathrm{Pt} 12(20 \mu \mathrm{M}), \mathrm{Pt} 12+\mathrm{anti}-\mathrm{MUC1}$ $(20 \mu \mathrm{M}+10 \mu \mathrm{g} / \mathrm{ml})$, cisplatin $(20 \mu \mathrm{M})$ and cisplatin + anti-MUC1 $(20 \mu \mathrm{M}+10 \mu \mathrm{g} / \mathrm{ml})$. The results are representative of data from 3 independent experiments. Data presented as the mean \pm standard deviation. $\mathrm{P}<0.05$, treated vs. untreated cells. MUC1, mucin 1; Pt12, platinum(II) complex.

$(10 \mu \mathrm{g} / \mathrm{ml})$ and cisplatin $(10$ and $20 \mu \mathrm{M})$, and the anti-MUC1 $(10 \mu \mathrm{g} / \mathrm{ml})$ in combination with Pt12 (10 and $20 \mu \mathrm{M})$. The results were compared with the control cells, cultured without drugs.

We measured the concentration of proapoptotic Bax protein (Fig. 1), which is a member of Bcl-2 family and promotes the release of cytochrome $c$ from mitochondria to cytosol. All the tested compounds significantly increased Bax concentration as compared to control. After $24 \mathrm{~h}$ of incubation with agents used in monotherapy, cisplatin in a dose of $20 \mu \mathrm{M}$ was a more potent inducer of Bax release. The effect was a little stronger than that produced by Pt12 and anti-MUC1 in two doses. The highest concentration of Bax was observed after combined treatment with Pt12 $(20 \mu \mathrm{M})$ and anti-MUC1 $(10 \mu \mathrm{g} / \mathrm{ml})$. The concentration of Bax was $150 \mathrm{ng} / \mathrm{ml}$ compared to reference compound cisplatin used with anti-MUC1 in the same doses, where the level of Bax was $142 \mathrm{ng} / \mathrm{ml}$.

Cytochrome $c$, a main mediator in intrinsic apoptotic marker activates the mitochondrial-dependent death in the cytosol. It binds to the cytosolic Apaf-1 and triggers the formation of an apoptosome, which recruits pro-caspase- 9 to its caspase recruitment domain (CARD) allowing activation and proteolysis. The effect of caspase-9 is the activation of executor caspases-3, -6 and -7 leading to cell death (36). In our study, we proved that all compounds increased the concentrations of cytochrome $c$ (Fig. 2) and caspase-9 (Fig. 3) as compared to control. Taking into account monotherapy, the highest concentration of cytochrome $c(860 \mathrm{ng} / \mathrm{ml})$ was observed after anti-MUC1 treatment in a dose of $20 \mu \mathrm{g} / \mathrm{ml}$. Taking into account the combined treatment, the highest concentration of the analysed marker $(707 \mathrm{ng} / \mathrm{ml})$ was observed after Pt12 $(20 \mu \mathrm{M})$ with anti-MUC1 $(10 \mu \mathrm{g} / \mathrm{ml})$ in comparison to the control $(300 \mathrm{ng} / \mathrm{ml})$.

We observed that Pt12 was a stronger inducer of caspase-9 release compared to cisplatin after $24 \mathrm{~h}$ of incubation with drugs. The concentrations of caspase- 9 after treatment with Pt12 and cisplatin alone were 90 and $77 \mathrm{ng} / \mathrm{ml}$, respectively.

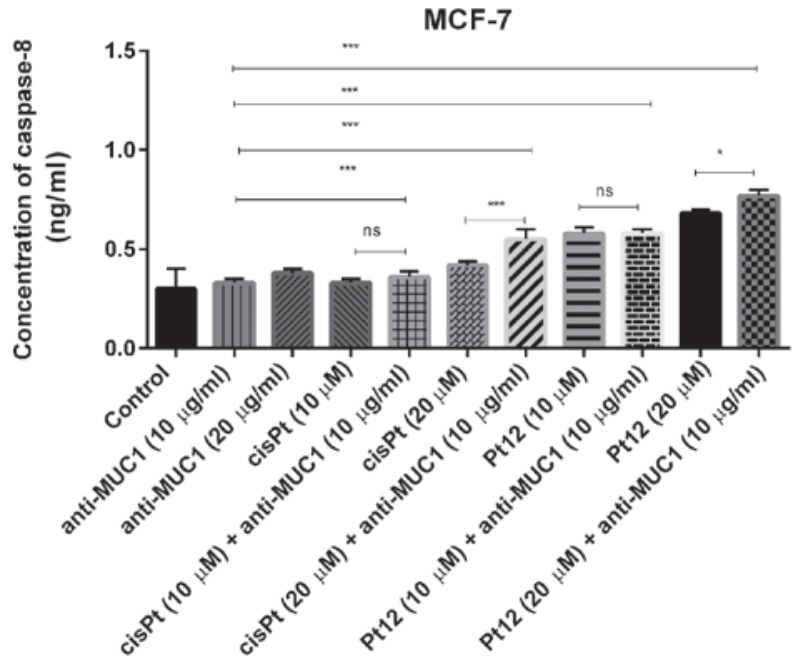

Figure 5. Concentration of caspase-8 in breast cancer MCF-7 cells following $24 \mathrm{~h}$ incubation with anti-MUC1 (10 and $20 \mu \mathrm{g} / \mathrm{ml}), \mathrm{Pt1} 2(10$ and $20 \mu \mathrm{M})$, Pt12 + anti-MUC1 $(10 \mu \mathrm{M}+10 \mu \mathrm{g} / \mathrm{ml}$ and $20 \mu \mathrm{M}+10 \mu \mathrm{g} / \mathrm{ml})$, cisplatin $(10$ and $20 \mu \mathrm{M})$, cisplatin + anti-MUC1 $(10 \mu \mathrm{M}+10 \mu \mathrm{g} / \mathrm{ml}$ and $20 \mu \mathrm{M}+10 \mu \mathrm{g} / \mathrm{ml})$. The results are representative of data from 3 independent experiments. Data presented as the mean \pm standard deviation. ${ }^{*} \mathrm{P}<0.05$ and ${ }^{* * * *} \mathrm{P}<0.001$, as indicated. MUC1, mucin 1; Pt12, platinum(II) complex; ns, not significant.

The strongest effect on caspase-9 release was determined after combined treatment with Pt12 $(20 \mu \mathrm{M})$ and anti-MUC1 $(10 \mu \mathrm{g} / \mathrm{ml})$. The concentration of caspase- 9 was $120 \mathrm{ng} / \mathrm{ml}$. After incubation with cisplatin $(20 \mu \mathrm{M})$ and anti-MUC1 $(10 \mu \mathrm{g} / \mathrm{ml})$, the level of caspase- 9 was $94 \mathrm{ng} / \mathrm{ml}$ (Fig. 3).

To confirm caspase-9 activation in MCF-7 breast cancer cells, we treated them with different concentrations of the compounds tested. Then we lysed the cells and detected the enzyme activity with flow cytometry. The average values showed that caspase-9 activity was raised 5.6-fold, respectively in the anti-MUC1+Pt12 treated cells as compared to the untreated control cells (Fig. 4). The difference was statistically 

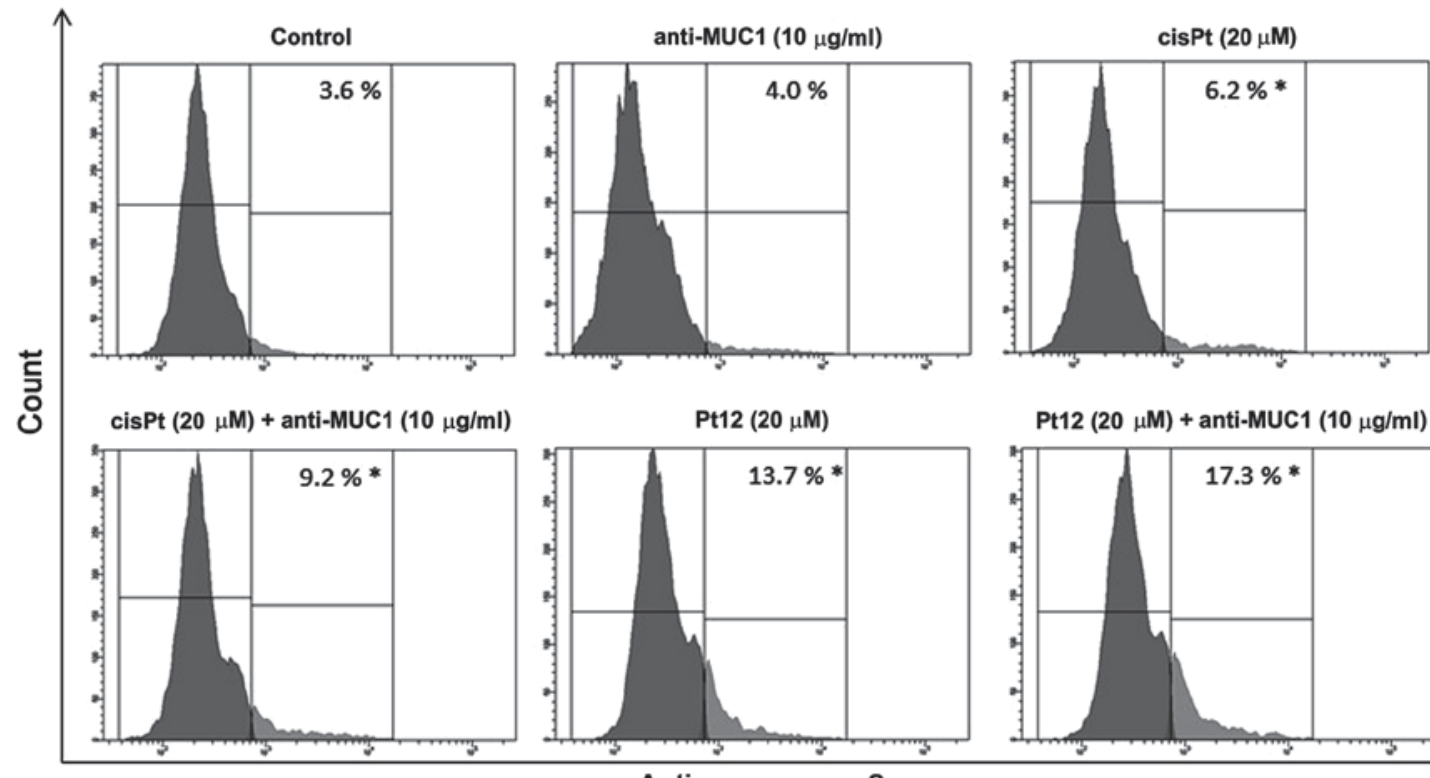

Pt12 $(20 \mu \mathrm{M})+$ anti-MUC1 $(10 \mu \mathrm{g} / \mathrm{ml})$

Active caspase-8

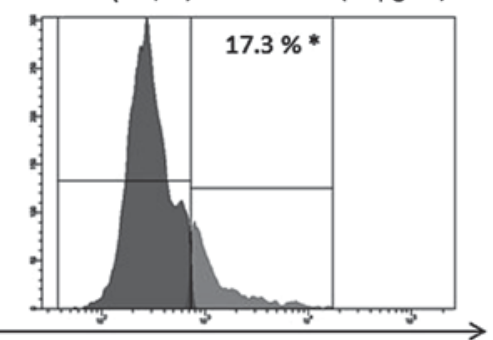

Figure 6. Activity of caspase- 8 in breast cancer MCF-7 cells following $24 \mathrm{~h}$ incubation with anti-MUC1 $(10 \mu \mathrm{g} / \mathrm{ml}), \mathrm{Pt} 12(20 \mu \mathrm{M}), \mathrm{Pt} 12+$ anti-MUC1 $(20 \mu \mathrm{M}+10 \mu \mathrm{g} / \mathrm{ml})$, cisplatin $(20 \mu \mathrm{M})$ and cisplatin + anti-MUC1 $(20 \mu \mathrm{M}+10 \mu \mathrm{g} / \mathrm{ml})$. The results are representative of data from 3 independent experiments. Data presented as the mean \pm standard deviation. "P<0.05, treated vs. untreated cells. MUC1, mucin 1; Pt12, platinum(II) complex.

significant $(\mathrm{P}<0.05)$. The results indicated that anti-MUC1 together with Pt12 activated the apoptosis initiator caspase-9 in the MCF-7 cells.

Impact of Pt12 combined with anti-MUCl antibody on the extrinsic apoptotic pathway. Caspase- 8 represents initiator caspases of the extrinsic apoptotic pathway and its activation results in the processing of the downstream effector caspases (caspase-3, -6, -7), which induce cell death. In monotherapy, we observed that only Pt12 in the doses of 10 and $20 \mu \mathrm{M}$ $(0.58$ and $0.68 \mathrm{ng} / \mathrm{ml})$ significantly increased caspase- 8 concentration in comparison with two doses of cisplatin ( 0.33 ; $0.42 \mathrm{ng} / \mathrm{ml})$ and anti-MUC1 (0.33 and $0.38 \mathrm{ng} / \mathrm{ml})$. However, the highest concentration of the apoptotic marker $(0.77 \mathrm{ng} / \mathrm{ml})$ was detected after combined treatment with Pt12 $(20 \mu \mathrm{M})$ and anti-MUC1 $(10 \mu \mathrm{g} / \mathrm{ml})$. The effect was over twice stronger in comparison with control (0.3 ng/ml) (Fig. 5).

To confirm caspase- 8 activation in MCF-7 breast cancer cells, we lysed the cells and detected the enzyme activity with flow cytometry. The average values showed that caspase- 8 activity was raised 4.8 -fold respectively in the anti-MUC1+Pt12 treated cells compared to the untreated control cells (Fig. 6). The differences were statistically significant $(\mathrm{P}<0.05)$. The results indicated that anti-MUC1+Pt12 activated the apoptosis initiator caspase- 8 in the MCF-7 cells. The activation of caspase- 8 enzymes suggested the involvement of combined therapy in the extrinsic apoptotic pathway.

Effect of Pt12 combined with anti-MUC1 antibody on the p53 concentration. P53 is a major tumor suppressor which upon DNA damage activates genes involved in either cancer cell growth arrest or apoptosis (37). We noticed that anti-MUC1 used in monotherapy in doses of 10 and $20 \mu \mathrm{g} / \mathrm{ml}$ reduced the concentration of p53 (1.2 and $0.38 \mathrm{U} / \mathrm{ml})$ in cell lysates in comparison with control $(13 \mathrm{U} / \mathrm{ml})$. Pt12 and cisplatin had no influence on 553 concentration, compared to control. We finally demonstrated that cisplatin and Pt12 together with anti-MUC1 significantly increased the level of p53 in comparison with monotherapy $(\mathrm{P}<0.05)$ (Fig. 7).

Pt12 combined with anti-MUCl antibody reduces the concentration of p-Akt in MCF-7 breast cancer cells. The key element of the study was to check the influence of combined treatment and monotherapy on the concentration of PI3K. The analyzed kinase is involved in PAM pathway, which is the most frequently altered pathway in human cancers.

We proved that monotherapy as well as combined treatment based on Pt12 with anti-MUC1 had no influence on the concentration of PI3K (Fig. 8). We also checked the effect of the tested compounds on the concentration of p-Akt, which takes part in the activation of target proteins involved in cell survival, proliferation, cell cycle and invasive potential of cells.

We demonstrated that treatment with compounds such as anti-MUC1 and cisplatin had no influence on concentration of p-Akt. The concentration was very similar to control $(\mathrm{P}>0.05)$. The novel berenil complex of platinum(II)-Pt12 significantly reduced the concentration of the analyzed phosphoprotein; however, the lowest concentration was detected after combined treatment. The concentration of p-Akt after treatment with Pt12 and anti-MUC1 was 3 ng/ml (Fig. 9). The combined treatment based on Pt12 or cisplatin with anti-MUC1 is involved in p-Akt inhibition. We observed statistically significant differences between combined treatment and monotherapy $(\mathrm{P}<0.05)$.

\section{Discussion}

Human cancer is a highly diverse and complex disease based on multiple etiologies, multiple cell targets and distinct developmental stages. A key process in the ability of tumor cells 


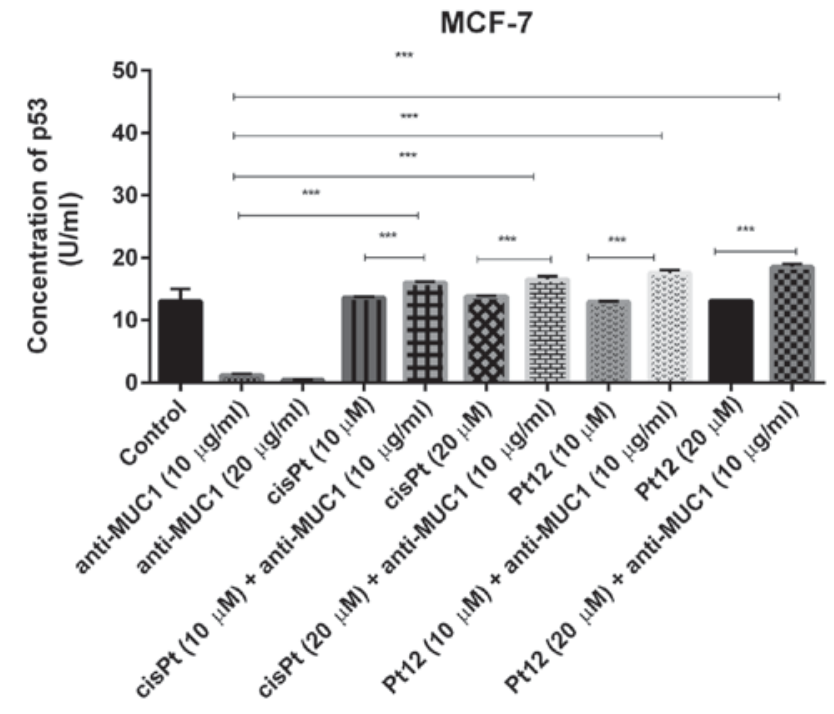

Figure 7. Concentration of p53 protein in breast cancer MCF-7 cells following $24 \mathrm{~h}$ incubation with anti-MUC1 (10 and $20 \mu \mathrm{g} / \mathrm{ml}), \mathrm{Pt1} 2(10$ and $20 \mu \mathrm{M}), \operatorname{Pt} 12+\operatorname{anti}-\mathrm{MUC1}(10 \mu \mathrm{M}+10 \mu \mathrm{g} / \mathrm{ml}$ and $20 \mu \mathrm{M}+10 \mu \mathrm{g} / \mathrm{ml})$, cisplatin $(10$ and $20 \mu \mathrm{M})$, cisplatin + anti-MUC1 $(10 \mu \mathrm{M}+10 \mu \mathrm{g} / \mathrm{ml}$ and $20 \mu \mathrm{M}+10 \mu \mathrm{g} / \mathrm{ml})$. The results are representative of data from 3 independent experiments. Data presented as the mean \pm standard deviation. ${ }^{* * *} \mathrm{P}<0.001$, as indicated. MUC1, mucin 1; Pt12, platinum(II) complex.

to expand locally is resistance to apoptosis. The suppression of apoptotic potential can involve the activation of antiapoptotic factors such as $\mathrm{Bcl}-2$ or loss of expression or mutation of proapoptotic factors such as p53 (38). However, cancer cell proliferation might be promoted by the production of growth factors such as PDGF and TGFa. Modern cancer treatment focuses on molecular defects of intracellular signal transduction pathways caused by genetic alterations that drive the oncogenesis. Aberrant expression of the PI3K-Akt-mTOR pathway is also known to play a critical role in cancer cell growth, proliferation and angiogenesis (39). Looking for new agents with proapoptotic potential or targeting PI3K/Akt/mTOR pathway are possible strategies in breast cancer treatment.

Recently, we confirmed that all the tested compounds induced apoptosis in MCF-7 and MDA-MB-231 cells, using several biochemical tests: flow cytometric analysis after Annexin V-FITC and propidium iodide (PI) staining, mitochondrial membrane potential and DNA fragmentation. This study confirmed that Pt12 with anti-MUC1 was a more active inhibitor of DNA and collagen synthesis as well as a more cytotoxic agent than Pt12 alone and cisplatin with anti-MUC1. Cytotoxicity of Pt12 with anti-MUC1 against breast cancer cells is due to apoptotic cell death as well as necrotic cell death. That study confirmed that combined treatment induced apoptosis, although the detailed mechanism was still unclear (35).

Apoptosis known as a programmed cell death is executed by a family of proteases called caspases. Caspases play a crucial role in the mechanism of apoptosis. Initiators (caspase-2, -8, -9, -10) are responsible for the beginning of apoptotic pathways and executors (caspase-3, -6 and -7) play central role in the cleavage of cellular components $(36,40)$. Recently, we checked the mechanism of Pt12 with anti-MUC1 using flow cytometry assessment of Annexin $\mathrm{V}$ binding assay. It was found that cytotoxicity of Pt12 with anti-MUC1 against

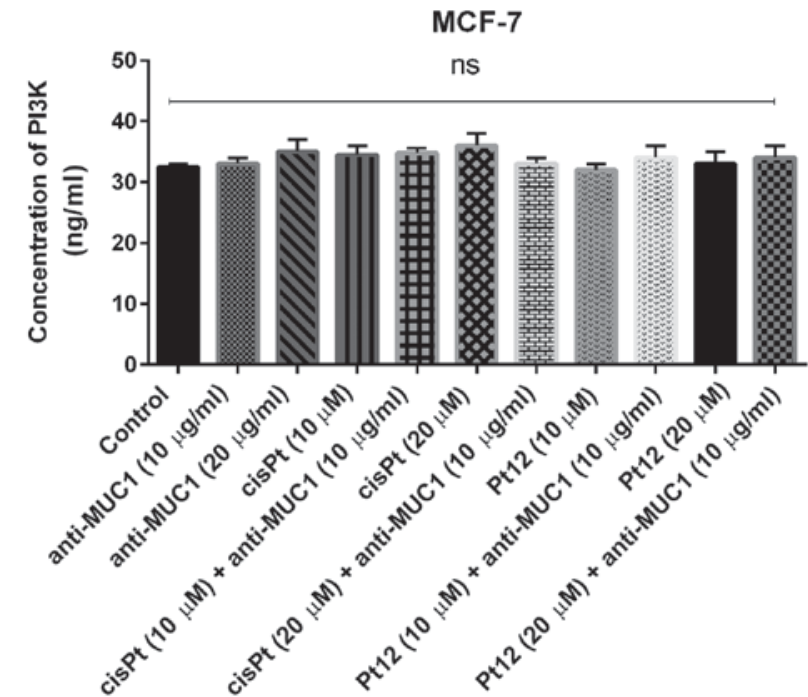

Figure 8. Concentration of PI3K in breast cancer MCF-7 cells following $24 \mathrm{~h}$ incubation with anti-MUC1 (10 and $20 \mu \mathrm{g} / \mathrm{ml}), \operatorname{Pt} 12(10$ and $20 \mu \mathrm{M})$, Pt12 + anti-MUC1 $(10 \mu \mathrm{M}+10 \mu \mathrm{g} / \mathrm{ml}$ and $20 \mu \mathrm{M}+10 \mu \mathrm{g} / \mathrm{ml})$, cisplatin $(10$ and $20 \mu \mathrm{M})$, cisplatin + anti-MUC1 $(10 \mu \mathrm{M}+10 \mu \mathrm{g} / \mathrm{ml}$ and $20 \mu \mathrm{M}+10 \mu \mathrm{g} / \mathrm{ml})$. The results are representative of data from 3 independent experiments. Data presented as the mean \pm standard deviation. MUC1, mucin 1; Pt12, platinum(II) complex; PI3K, phosphoinositide 3 kinase; ns, not significant.

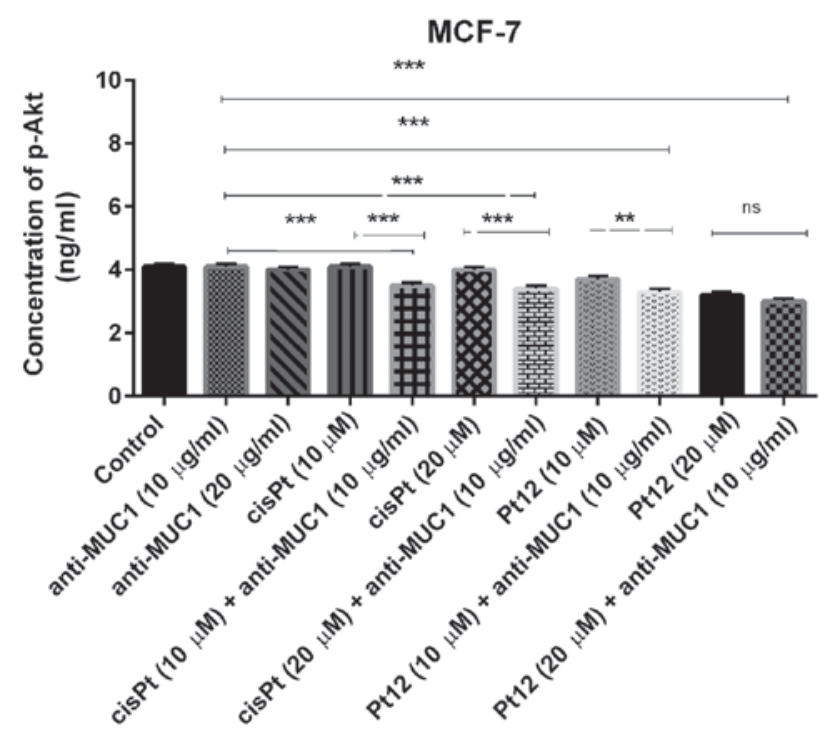

Figure 9. Concentration of p-Akt in breast cancer MCF-7 cells following $24 \mathrm{~h}$ incubation with anti-MUC1 (10 and $20 \mu \mathrm{g} / \mathrm{ml}), \operatorname{Pt} 12(10$ and $20 \mu \mathrm{M})$, Pt12 + anti-MUC1 $(10 \mu \mathrm{M}+10 \mu \mathrm{g} / \mathrm{ml}$ and $20 \mu \mathrm{M}+10 \mu \mathrm{g} / \mathrm{ml})$, cisplatin $(10$ and $20 \mu \mathrm{M})$, cisplatin + anti-MUC1 $(10 \mu \mathrm{M}+10 \mu \mathrm{g} / \mathrm{ml}$ and $20 \mu \mathrm{M}+10 \mu \mathrm{g} / \mathrm{ml})$. The results are representative of data from 3 independent experiments. Data presented as the mean \pm standard deviation. ${ }^{* *} \mathrm{P}<0.01$ and ${ }^{* * *} \mathrm{P}<0.001$, as indicated. MUC1, mucin 1; Pt12, platinum(II) complex; p-Akt, phosphorylated protein kinase B; ns, not significant.

breast cancer cells is due to apoptotic cell death as well as necrotic cell death, although detailed characteristics was still unknown (35). In that study, we demonstrated higher levels of proapoptotic Bax, cytochrome $c$ and two initiator caspases such as caspase- 8 and caspase-9, which represent two different apoptotic pathways. Our results proved that Pt12 together with anti-MUC1 induced apoptosis by the extrinsic and intrinsic cell death pathways. 
Some authors have shown that MUC1 interacts with p53 and leads to the activation of p21, a main player in the prevention of apoptosis and abrogation of the transcription of Bax (41). Other researchers indicate that increased expression of p53 is responsible for the blockade of cell cycle and contribute to the induction of apoptosis (42). We demonstrated that only combined treatment with both chemotherapeutic agents (cisplatin and Pt12) significantly increased the concentration of $\mathrm{p} 53$. The results obtained after the incubation with cisplatin or Pt12 together with anti-MUC1 antibody proved that the role of p53 in apoptosis induction is uncontested. After the incubation with cisplatin or Pt12 alone, we observed that the concentration of p53 is similar in comparison with control. However, anti-MUC1 antibody reduced the concentration of the protein tested as compared to control. Monotherapy led to the induction of apoptosis in another way, independently of p53 protein. Abeysinghe et al (43) proved that the novel iron chelator, tachypyridine [N,N',N'-tris (2-pyridylmethyl)-cis, cis-1,3,5-triaminocyclohexane] initiates an apoptotic mode of cell death that does not require functional p53. Some human tumors contain a functionally defective p53, that reduces sensitivity to commonly used chemotherapeutic drugs, such as cisplatin, so induction of apoptosis independently of p53 may be an advantage in anticancer treatment (43).

The literature data show a link between MUC1 and PI3K/Akt pathway. MUC1 acts as an oncoprotein through the PI3K-Akt pathway and promotes the growth and survival of cancer cells. Kosugi et al (44) have demonstrated that MUC1 C-terminal subunit is involved in the regulation of glucose uptake and lactate production in MUC1-C-induced transformation of rat fibroblasts and in human breast cancer cells. The results also proved that the MUC1 cytoplasmic domain interacts directly with PKM2 and regulates PKM2 activity. MUC1 stimulates glycolysis through phosphoinositide 3 kinase and serine/threonine kinase (PI3K-Akt) (44). Other studies have demonstrated that MUC1-C activates the PI3K->Akt pathway, which in turn stimulates the activity of the glycolytic enzymes, hexokinase and phosphofructose kinase (16). Raina et al (45) have shown that MUC1 C-terminal subunit (MUC1-C) cytoplasmic domain associates with PI3K p85 in non small lung cancer cells. The inhibition of MUC1-C with cell-penetrating peptides blocks this interaction with PI3K p85 and suppresses constitutive phosphorylation of Akt and its downstream effector, mTOR. They tested MUC1-C peptide inhibitor GO-203, which was responsible for downregulation of $\mathrm{PI} 3 \mathrm{~K} \rightarrow$ Akt signaling and inhibition of growth cancer cells (45). Woo et al (46) also showed the relationship between the activation of the PI3K-Akt by MUC1 and angiogenesis mediated by VEGF. The present results show the inhibition of p-Akt after treatment with Pt12 and anti-MUC1 antibody. The concentration of PI3K was unchanged in comparison with control sample, thus suggesting that Akt is inhibited independently of PI3K.

The present study has some limitations associated with lack of usage of more than one cell line, but we showed that combined treatment is a promising strategy in anticancer treatment and represents the alternative to monotherapy. All compounds used alone (Pt12, cisplatin, anti-MUC1 antibody) increased the concentration of proapoptotic Bax, cytochrome $c$ and caspase-9 in comparison with control, thus suggesting that they activate the mitochondrial apoptotic pathway. Pt12 alone significantly increased the concentration of caspase- 8 responsible for the initiation of the extrinsic apoptotic pathway. However, the strongest effect was observed after Pt12 combined with anti-MUC1 antibody. These two compounds added together strongly induced apoptosis in MCF-7 breast cancer cells by external and internal apoptotic pathways. We also demonstrated that combined treatment based on Pt12 and anti-MUC1 antibody significantly reduced p-Akt concentration.

The obtained results should be confirmed by more experimental methods such as WB, qPCR, cell cycle analysis, TUNEL etc and in vivo studies are also required.

In summary, the present study revealed that combined treatment based on Pt12 and anti-MUC1 antibody with its proapoptotic activity, p-Akt inhibitory properties might be a promising strategy in breast cancer treatment.

\section{Acknowledgements}

This study was supported by research grant N/ST/MN/17/001/2229 from Medical University of Bialystok (Bialystok, Poland).

\section{References}

1. Rahn JJ, Dabbagh L, Pasdar M and Hugh JC: The importance of MUC1 cellular localization in patients with breast carcinoma: An immunohistologic study of 71 patients and review of the literature. Cancer 91: 1973-1982, 2001.

2. Horm TM and Schroeder JA: MUC1 and metastatic cancer. Expression, function and therapeutic targeting. Cell Adh Migr 7: 187-198, 2013.

3. Singh PK and Hollingsworth MA: Cell surface-associated mucins in signal transduction. Trends Cell Biol 16: 467-476, 2006.

4. Schroeder JA, Thompson MC, Gardner MM and Gendler SJ: Transgenic MUC1 interacts with epidermal growth factor receptor and correlates with mitogen activated protein kinase activation in the mouse mammary gland. J Biol Chem 276: 13057-13064, 2001.

5. Pochampalli MR, el Bejjani RM and Schroeder JA: MUC1 is a novel regulator of ErbB1 receptor trafficking. Oncogene 26: 1693-1701, 2007

6. Rahn JJ, Chow JW, Horne GJ, Mah BK, Emerman JT, Hoffman P and Hugh JC: MUC1 mediates transendothelial migration in vitro by ligating endothelial cell ICAM-1. Clin Exp Metastasis 22: 475-483, 2005 .

7. Regimbald LH, Pilarski LM, Longenecker BM, Reddish MA, Zimmermann G and Hugh JC: The breast mucin MUCI as a novel adhesion ligand for endothelial intercellular adhesion molecule 1 in breast cancer. Cancer Res 56: 4244-4249, 1996.

8. Li Q, Ren J and Kufe D: Interaction of human MUC1 and beta-catenin is regulated by Lck and ZAP-70 in activated Jurkat T cells. Biochem Biophys Res Commun 315: 471-476, 2004.

9. Li Y, Kuwahara H, Ren J, Wen G and Kufe D: The c-Src tyrosine kinase regulates signaling of the human DF3/MUC1 carcinoma-associated antigen with GSK3 beta and beta-catenin. J Biol Chem 276: 6061-6064, 2001.

10. Li Y, Chen W, Ren J, Yu WH, Li Q, Yoshida K and Kufe D: DF3/MUC1 signaling in multiple myeloma cells is regulated by interleukin-7. Cancer Biol Ther 2: 187-193, 2003.

11. Mukherjee P, Tinder TL, Basu GD and Gendler SJ: MUC1 (CD227) interacts with lck tyrosine kinase in Jurkat lymphoma cells and normal T cells. J Leukoc Biol 77: 90-99, 2005.

12. Al MA and Gendler SJ: Mucl affects c-Src signaling in PyV MT-induced mammary tumorigenesis. Oncogene 24: 5799-5808, 2005.

13. Yamamoto M, Bharti A, Li Y and Kufe D: Interaction of the DF3/MUC1 breast carcinoma-associated antigen and beta-catenin in cell adhesion. J Biol Chem 272: 12492-12494, 1997. 
14. Wei X, Xu H and Kufe D: MUC1 oncoprotein stabilizes and activates estrogen receptor alpha. Mol Cell 21: 295-305, 2006.

15. Ren J, Bharti A, Raina D, Chen W, Ahmad R and Kufe D MUC1 oncoprotein is targeted to mitochondria by heregulininduced activation of c-Src and the molecular chaperone HSP90. Oncogene 25: 20-31, 2006.

16. Raina D, Kharbanda S and Kufe D: The MUC1 oncoprotein activates the antiapoptotic phosphoinositide 3-kinase/Akt and Bcl-xL pathways in rat 3 Y1 fibroblasts. J Biol Chem 279: 20607-20612, 2004.

17. Lee JJ, Loh K and Yap YS: PI3K/Akt/mTOR inhibitors in breast cancer. Cancer Biol Med 12: 342-354, 2015.

18. Castaneda CA, Cortes-Funes H, Gomez HL and Ciruelos EM: The phosphatidyl inositol 3-kinase/AKT signaling pathway in breast cancer. Cancer Metastasis Rev 29: 751-759, 2010.

19. Chitnis MM, Yuen JS, Protheroe AS, Pollak M and Macaulay VM: The type 1 insulin-like growth factor receptor pathway. Clin Cancer Res 14: 6364-6370, 2008.

20. Cantley LC: The phosphoinositide 3-kinase pathway. Science 296: 1655-1657, 2002.

21. Baselga J: Targeting the phosphoinositide-3 (PI3) kinase pathway in breast cancer. Oncologist 16 (Suppl 1): S12-S19, 2011.

22. Ito K, Bernardi R and Pandolfi PP: A novel signaling network as a critical rheostat for the biology and maintenance of the normal stem cell and the cancer-initiating cell. Curr Opin Genet Dev 19 51-59, 2009.

23. Hirsch E, Ciraolo E, Ghigo A and Costa C: Taming the PI $3 \mathrm{~K}$ team to hold inflammation and cancer at bay. Pharmacol Ther 118: 192-205, 2008

24. Dowling RJO, Topisirovic I, Fonseca BD and Sonenberg N: Dissecting the role of mTOR: Lessons from mTOR inhibitors. Biochim Biophys Acta 1804: 433-439, 2010.

25. Kenerson HL, Aicher LD, True LD and Yeung RS: Activated mammalian target of rapamycin pathway in the pathogenesis of tuberous sclerosis complex renal tumors. Cancer Res 62: 5645-5650, 2002.

26. Sarbassov DD, Guertin DA, Ali SM and Sabatini DM: Phosphorylation and regulation of Akt/PKB by the rictor-mTOR complex. Science 307: 1098-1101, 2005.

27. Lippert B (ed): Cisplatin: Chemistry and biochemistry of a leading anticancer drug. Wiley-VCH, Basel, pp3, 1999.

28. Bielawski K, Bielawska A,Popławska B and Bołkun-Skórnicka U: Synthesis, DNA-binding affinity and cytotoxicity of the dinuclear platinum(II) complexes with berenil and amines ligands. Acta Pol Pharm 65: 363-370, 2008.

29. Barcelo F, Ortiz-Lombardia M and Portugal J: Heterogeneous DNA binding modes of berenil. Biochim Biophys Acta 1519 $175-184,2001$

30. Nguyen B, Hamelberg D, Bailly C, Colson P, Stanek J, Brun R, Neidle $S$ and Wilson WD: Characterization of a novel DNA minor-groove complex. Biophys J 86: 1028-1041, 2004.

31. Czarnomysy R, Bielawski K, Muszynska A, Bielawska A and Gornowicz A: Biological evaluation of dimethylpyridine-platinum complexes with potent antiproliferative activity. J Enzyme Inhib Med Chem 31: 150-165, 2016.

32. Bielawski K, Czarnomysy R, Muszyńska A, Bielawska A and Popławska B: Cytotoxicity and induction of apoptosis of human breast cancer cells by novel platinum(II) complexes. Environ Toxicol Pharmacol 35: 254-264, 2013.
33. Bielawska A, Popławska B, Surazyński A, Czarnomysy R and Bielawski K: Cytotoxic efficacy of a novel dinuclear platinum(II) complex in human breast cancer cells. Eur J Pharmacol 643 34-41, 2010.

34. Bielawski K, Bielawska A, Popławska B, Surazyński A and Czarnomysy R: The effect of a novel dinuclear platinum complex with berenil and 2-picoline ligands on growth of human breast cancer cells. Acta Pol Pharm 67: 609-614, 2010.

35. Gornowicz A, Kałuża Z, Bielawska A, Gabryel-Porowska H, Czarnomysy $\mathrm{R}$ and Bielawski K: Cytotoxic efficacy of a novel dinuclear platinum(II) complex used with anti-MUC1 in human breast cancer cells. Mol Cell Biochem 392: 161-174, 2014.

36. Pistritto G, Trisciuoglio D, Ceci C, Garufi A and D'Orazi G: Apoptosis as anticancer mechanism: Function and dysfunction of its modulators and targeted therapeutic strategies. Aging (Albany NY) 8: 603-619, 2016.

37. Vousden KH and Lane DP: P53 in health and disease. Nat Rev Mol Cell Biol 8: 275-283, 2007.

38. Kim HJ, Hawke $\mathrm{N}$ and Baldwin AS: NF-kappaB and IKK as therapeutic targets in cancer. Cell Death Differ 13: 738-747, 2006.

39. Dey N, Sun Y, Carlson JH, Wu H, Lin X, Leyland-Jones B and De P: Anti-tumor efficacy of BEZ235 is complemented by its anti-angiogenic effects via downregulation of PI3K-mTOR-HIF1alpha signaling in HER2-defined breast cancers. Am J Cancer Res 6: 714-746, 2016.

40. Thomberry NA and Laxebnik Y: Caspases: Enemies within. Science 281: 1312-1316, 1998

41. Wei X, Xu H and Kufe D: Human MUC1 oncoprotein regulates p53-responsive gene transcription in the genotoxic stress response. Cancer Cell 7: 167-178, 2005.

42. Lutz W and Nowakowska-Swirta E: Gene p53 mutations, protein p53, and anti-p53 antibodies as biomarkers of cancer process. Int J Occup Med Environ Health 15: 209-218, 2002.

43. Abeysinghe RD, Greene BT, Haynes R, Willingham MC, Turner J, Planalp RP, Brechbiel MW, Torti FM and Torti SV: p53-independent apoptosis mediated by tachpyridine, an anti-cancer iron chelator. Carcinogenesis 22: 1607-1614, 2001

44. Kosugi M, Ahmad R, Alam M, Uchida Y and Kufe D: MUC1-C oncoprotein regulates glycolysis and pyruvate kinase M2 activity in cancer cells. PLoS One 6: e28234, 2011.

45. Raina D, Kosugi M, Ahmad R, Panchamoorthy G, Rajabi H, Alam M, Shimamura T, Shapiro GI, Supko J, Kharbanda S and Kufe D: Dependence on the MUC1-C oncoprotein in non-small cell lung cancer cells. Mol Cancer Ther 10: 806-816, 2011.

46. Woo JK, Choi Y, Oh SH, Jeong JH, Choi DH, Seo HS and Kim CW: Mucin 1 enhances the tumor angiogenic response by activation of the AKT signaling pathway. Oncogene 31: 2187-2198, 2012.

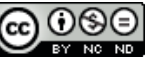

This work is licensed under a Creative Commons Attribution-NonCommercial-NoDerivatives 4.0 International (CC BY-NC-ND 4.0) License. 